\title{
Epilepsi Tanılı Çocuklarda Uzun Süreli Valproik Asit Monoterapisinin Hematolojik ve Biyokimyasal Parametreler Üzerine Etkisi
}

\author{
The Effect of Long-Term Valproic Acid Monotherapy on Hematological and \\ Biochemical Parameters in Children with Epilepsy
}

\author{
(D)Ercan Kayış ${ }^{1}$, ĐResul Yılmaz ${ }^{2}$, ĐErhan Karaaslan ${ }^{3}$ \\ ${ }^{1}$ Amasya Sabuncuoğlu Şerafeddin Training and Research Hospital, Clinic of Pediatrics, Amasya, Turkey \\ ${ }^{2}$ Selcuk University School of Medicine Department of Pediatrics, Division of Pediatric Critical Care, Konya, Turkey \\ ${ }^{3}$ Gaziosmanpasa University School of Medicine Department of Pediatrics, Tokat, Turkey
}

\section{ÖZ}

Amaç: $\mathrm{Bu}$ çalışmanın amacı epilepsi tanılı çocuk hastalarda valproik asidin (VPA) uzun süreli hematolojik ve biyokimyasal yan etkilerini belirlemektir.

Gereç ve Yöntem: Geriye dönük bir doğal çalışma tasarımı kullanılmıştır. Katılımcılar, monoterapi şeklinde yalnızca VPA ile tedavi edilen epilepsi saptanan çocuk hastalardı. Elektronik tıbbi dosyalar, bir VPA tedavisi öncesi ve sonrasında hematolojik ve biyokimyasal parametrelerdeki değişiklikler için gözden geçirildi.

Bulgular: Yaşları 3-18 (ort. 10,52 $\pm 3,63$ ) yıl olan 85 hasta çalışma kriterlerini karşıladı. Hastaların 50'sini $(\% 58,9)$ kızlar oluşturmaktaydı. Tedaviye başladıktan sonraki ikinci yılda hastaların Trombosit değerleri VPA kullanan hastalarda ortalama 249,320 \pm 48,778 /mm3 olarak hesaplanmıştır ve yıllar içindeki bu farklılık istatistiksel olarak anlamlıdır $(p=0,005)$. Hastaların tedaviye başlamadan önceki ALT, LDH ve ALP değerleri cinsiyete göre ve tedavi yıllarına göre anlamlı farklılık göstermemiştir. ( $p>0,05)$. Hastaların GGT değerleri yıllar içinde başlangıca göre artma göstermiş olup bu farklılık istatistiksel olarak anlamlıdır ( $F=4,359$, $p=0,02)$. Hiçbir ciddi yan etki bildirilmedi.

Sonuç: VPA ile tedavi edilen epileptik hastalar, trombosit sayısında azalma ve karaciğer enzimlerinde yükselme riski altında olabilir. Bu nedenle, karaciğer fonksiyonlarının ve hematolojik parametrelerin temel ölçümü ve tedavi boyunca izlenmesi önerilir.

Anahtar Kelimeler: Valproik asit, yan etkiler, hematolojik, trombositopeni, karaciğer enzimleri

\section{ABSTRACT}

Objective: The aim of this study is to determine the longterm hematological and biochemical side effects of val proic acid (VPA) in pediatric patients with epilepsy.

Material and Method: A retrospective natural study design was used. Participants were pediatric patients with epilepsy who were treated with VPA only as monotherapy. Electronic medical files were reviewed for changes in hematological and biochemical parameters before and after a VPA treatment.

Results: Eighty-five patients aged 3-18 (mean $10.52 \pm$ 3.63) met the study criteria. 50 (58.9\%) of the patients were girls. In the second year after starting the treatment, the platelet values of the patients were calculated as $249.32 \pm$ 48.778 in patients using VPA, and this difference over the years is statistically significant. No serious side effects were reported.

Conclusion: Epileptic patients treated with VPA may be at risk of decreased platelet count and elevated liver enzymes. Therefore, baseline measurement of liver function and haematological parameters and monitoring during therapy is recommended.

Keywords: valproic acid, side effects, hematology, thrombocytopenia, liver enzymes 


\section{GíRiş}

Epilepsi insanoğlu tarafından bilinen en eski nörolojik hastalıklar arasında yer almaktadır (1). Farklı etiyolojik faktörlere bağlı olarak ortaya çıkmakta olup tekrarlayıcı sıklıkla spontan olarak gözlenen, aralarında 24 saatten daha uzun sürede tekrarlayan, tetikleyici neden olmadan, iki yahut daha fazla nöbet ile karakterize, kronik seyirli bir semptomlar dizisidir $(2,3)$.

Epilepsinin insidans ve prevalansındaki değişmeler sosyo-ekonomik düzey, çevresel faktörlerden kaynaklı olumsuzluklar nedeniyle olabilmektedir (4).

Epilepsi, hastaların fiziksel değişikliklere, günlük ilaç kullanımında tedavi şekline uyma, tekrarlayan doktor muayeneler ve akut tıbbi acil durumlara hazırlıklı olmasını gerektiren ve bu bağlamda da yaşam kalitesini negatif yönde etkileyen ciddi bir sağlık sorunudur (4). Yapılan çalışmalarda epilepsi hastalarının yaşam kalitesinin sağlıklı populasyona oranla daha düşük olduğu bildirilmiştir (5). Bu bilgiler dikkate alındığında hastaların düzenli tedavi almaları önem arz etmektedir.

Epilepsi tedavisindeki ilk aşama tanının doğru konması ve ilaçla tedaviye gerek olup olmadığının tespitidir. Tanıdan tam manasıyla emin olunmasının ardından diğer aşama ilaç tedavisine gerek olup olmadığına karar verilmesidir. Tek nöbet sonrası yineleme riski 6 ay içinde \%50 dolayındadır. 2 yıllık süre zarfında tekrarlanmaz ise nöbetin tekrarlanma riski de dolayısıyla düşmektedir. $\mathrm{Bu}$ sebepten ötürü bazı durumlarda uzun sürecek, yan etkileri olabilecek ve belki de gereksiz olan bir tedaviye başlanmadan önce hastalığın doğal seyrinin takip edilmesi oldukça faydalıdır. Hastalıktan emin olunmasından sonra uygun ilacın seçilmesi önemlidir. Epilepsi tedavisinde kullanılan ilaçlar antiepileptik ilaçlar (AEI) olarak adlandırılmakta olup VPA ise bunlar içinde en yaygın kullanılanlar arasında yer almaktadır (2).

Epilepsi tedavisinin uzun yıllar boyunca ve hastaların büyük çoğunluğunda ömür boyu devam edecek olması, ortaya çıkması muhtemel diğer hastalıklar, yaşlanma ve gebelik gibi durumlar açısından da AEI'lerin seçimini ve bir bütün olarak tedavinin hastanın özelliklerine göre bireyselleştirilmesini zorunlu hale getirmektedir (3).

Epilepsi söz konusu olunca çocuklarda iyi seyirli epilepsi grubu hariç hepsine ilaç başlanmaktadır. Yine epilepsi hastalarının yaklaşık \%40'ı ilaç bağımlı ve dirençli epilepsi grubu olup bunlar yaşam boyu bir yahut birkaç ilacı kullanmak zorundadırlar6. VPA epilepsi tedavisinde monoterapi veya politerapi dahilinde en sık kullanılan antiepileptikler arasında yer almaktadır $(7,8)$.

Geniş bir antikonvülzan aktivite spektrumuna sahip basit, dallı zincirli yağ asidi olan valproik asit (VPA), genellikle çeşitli epilepsi türlerinin tedavisi için kullanılan bir ilaçtır $(9,10)$. Diğer antikonvülzan ilaçlarda olduğu gibi VPA'nın temel etki mekanizması tam olarak bilinmemektedir. Yaygın olarak kabul edilen etki mekanizması VPA'nın voltaja duyarlı sodyum kanalları üzerinden gama amino bütirik asidin (GABA) etkilerini arttırmasıdır. Ayraca sinyal transdüksiyon sistemi ara kademeleri üzerinde düzenleyici etkileri bulunmakta ve voltaj kapılı sodyum kanallarından iyonların geçişini yavaşlatarak abartılı nöronal iletiyi hafifletmektedir. VPA'nın sodyumun nöronlara geçişini azaltarak glutamat salınımını azalttığı ve eksitatör nöronların inhibe olmasını sayladığı; GABA'nın salıverilmesini arttırarak, geri alımını azaltarak ve/veya yıkımını yavaşlatarak inhibitör etkiyi artırdığı bilinmektedir. Bu etkilerden hangilerinin terapötik etkilere aracılık ettiği tam olarak bilinmemektedir (11).

VPA geleneksel olarak çocuklarda epilepsi tedavisi için kullanıldığından, epileptik çocuk hastalarda yan etkileri üzerine kapsamlı bir literatür oluşturulmuştur $(2,12)$. VPA tedavisi, çoğu epilepsi tedavisinde bildirilen çeşitli metabolik ve biyokimyasal yan etkilere neden olur (13-16). En ciddi yan etkiler, her ikisi de ölümcül olabilen hepatotoksisite ve pankreatittir (17-19). Bu ciddi advers olayların yanı sıra VPA, birçok hematolojik ve biyokimyasal parametreleri de etkiler: VPA nispeten eski bir antiepileptik ilaç olmasına rağmen, kanıtlanmış terapötik faydaları ve olumlu güvenlik profili nedeniyle popülerliğini korumaktadır (2).

Çocuklarda yürütülen çeşitli araştırmalardan elde edilen sonuçlar, VPA'nın epilepsiye ek olarak psikiyatrik hastalıkların tedavisinde de güvenli ve etkili olduğunu göstermiştir (20-24).

Epilepsi çoğunlukla kronik olduğundan ve özellikle çocuk popülasyonunda uzun süreli tedavi gerektirdiğinden, bu popülasyonda uzun vadeli VPA tedavisinin güvenliğini ve tolere edilebilirliğini incelemek önemlidir. Bu çalışmanın amacı, VPA ile tedavi edilen epilepsi tanılı çocuk hastalarda VPA tedavisinin beyaz kan hücresi (WBC) ve trombosit (PLT) sayısı ve karaciğer fonksiyon testleri (LFT'ler) üzerindeki uzun vadeli etkilerini araştırmaktı.

\section{GEREÇ VE YÖNTEM}

Çalışmamıza 30.01.2007 tarihi ile 30.12.2013 yılları arasında Tokat Gaziosmanpaşa Üniversitesi Tıp Fakültesi, Çocuk Sağlığı ve Hastalıkları kliniğine başvuran ICD10 kodlamasına göre G40.8(epilepsiler,diğer), G40.9(epilepsi,tanımlanmamış), R56.8 (konvulziyonlar diğer ve tanımlanmamış) tanıları almış olan hastalar tarandı. R56.8 ICD10 kodlu hastaların dosyaları yeniden incelendiğinde Epilepsi tanısı olanlar dikkate alındı. Buna göre toplam 1127 başvuruya ulaşıldı. Bu başvurular tekil hasta olarak 342 idi. Hastanemiz çocuk polikliniğinde ilk kez tanı almış ve antiepileptik tedavi alan 134 hasta çalışmaya alındı. Bu hastaların 4 ünde fenobarbital, 3 hastada levetirasetam, 2 hastada lamotrijin, 20 hastada karbamazepin kullanıldığı tespit edildi. Bu hastalar 
çalışma dışı bırakıldı. VPA kullanan 16 hasta, sadece 1 kez başvuru yaptığı ve ilaç sonrası başvuruları olmadığından eksik tetkik olması nedeniyle çalışma dışı bırakıldı.

Kliniğimizde VPA aşağıdaki gibi uygulanmıştır. Başlangıç Tedavisi: 1 ila 3 bölünmüş dozda 10 ila 15 mg/kg/gün; nöbetler kontrol altına alınana veya yan etkiler daha fazla artışı engelleyene kadar haftalık aralıklarla 5 ila 10 mg/kg/gün artırılmış; > 250 mg günlük dozlar bölünmüş dozlar halinde verilmişdir. İdame tedavi: 2 ila 3 bölünmüş dozda 30 ila 60 mg/kg/gün

Çalışmaya dâhil edilme kriterleri olarak; 0-18 yaşları arasında olmak, tekli antiepileptik alıyor olmak, antiepileptik tedavisine başlamadan önce herhangi bir antiepileptikler başta olmak üzere başka bir ilaç kullanmıyor olmak, eşlik eden başka hastalığın (ailevi hiperlipidemiler, konjenital, metabolik hastalıklar gibi) olmaması, hemogram ve biokimyasal tetkik değerlerine ulaşılabilir olmak olarak belirlendi. Çalışmanın dışlanma kriterleri olarak; 18 yaşından büyük olmak, kombine antiepileptik kullanıyor olmak, komorbid hastalığın olması, ek başka ilaç kullanıyor olmak, hemogram ve biokimyasal tetkik değerlerine ulaşılamıyor olmak olarak belirlendi.

Çalışmamıza hastane bilgi sisteminde hemotolojik ve biokimyasal tetkik değerleri mevcut olan, VPA kullanan hastalar alındı. Araştırmaya dahil edilen hastaların VPA tedavisi başlamadan hemen önceki laboratuvar değerleri ve AEI tedavi başlanması sonrası 1. yıl ve 2 . yıl laboratuvar değerleri karşılaştırıldı. Hemoglobin (Hb), Hematokrit (Hct), Platelet (plt), MCV, WBC, Alanin transaminaz (ALT), Aspartat transaminaz (AST), Gama glutamil transferaz (GGT), Alkalen fosfataz (ALP), Laktat dehidrogenaz (LDH) parametreleri değerlendirildi. Araştırmaya dahil edilen laboratuvar verileri epilepsi dışında sağlıklı olduğu dönemde, rutin epilepsi takibi sırasında istenen testlerden alınmıştır. Klinik ve laboratuvar olarak viral ya da bakteriyel enfeksiyon olabilecek durumlar dışlanmıştır.

Bu parametrelerin hastanemizde çalışılma teknikleri: AST ve ALT: Absorbanstaki azalmanın ölçülmesiyle fotometrik olarak tayin edilmiş. GGT: Enzimatik kolorimetrik test, Absorbanstaki artmanın ölçülmesiyle fotometrik olarak tayin edilmiş. LDH: UV testi, Absorbanstaki artmanın ölçülmesiyle fotometrik olarak tayin edilmiş. ALP: Kolorimetrik test, Absorbanstaki artış ölçülerek tayin edilmiş. Değerlendirmede esas alınan biyokimyasal parametrelerin referans aralıkları pediatri pratiğinde başucu kaynağı olan Nelson Textbook of Pediatrics temel alınmıştır.25.

\section{Etik Durum}

Bu araştırmada 2020 öncesi veriler kullanılmış ve araştırma 2020 öncesinde sonuçlanmıştır. Yazarın 2014 yılında sunulan EPILEPTIK HASTALARDA VALPROIK ASIT
VE KARBAMAZEPIN'IN HEMATOLOJIK VE BIYOKIMYASAL PARAMETRELERE ETKISI başlıklı tezinden üretilmiştir. 3 Kasım 2015 tarihli 28617 sayılı olarak resmi gazetede yayınlanan Klinik Araştırmalar Hakkında Yönetmelik'e göre "Retrospektif çalışmalar yönetmeliğin kapsamı dışındadır (madde 2-(2))"maddesi gereği etik kurul onayı alınmamıştır. Bu çalışma Kişisel Verilerin Korunması Kanununa uygun şekilde hasta verileri anonim hale getirtilerek ve İyi Kilinik Uygulamalar ve Helsinki Deklarasyonun 2013 Brezilya güncellemesine uygun olarak hazırlanmıştır.

\section{İstatistiksel Analiz}

Çalışmanın analizleri SPSS 21.0 istatistik paket programı kullanılarak yapılmıştır. Kategorik veriler sayı ve yüzdeler ile, niteliksel veriler ise ortalama ve standart sapma şeklinde özetlenmiştir. Verilerin normal dağılıma uygunluğu Kolmogrow-Smirnow testi ile kontrol edilmiştir. Kategorik verilerin karşılaştırılmasında ki-kare testi, yıllara göre ölçümler için Tekrarlayan Ölçümlerde Varyans Analizi kullanılmıştır. P değeri 0,05'ten küçük olduğunda anlamlı kabul edildi.

\section{BULGULAR}

\section{Katılımcılar}

Epilepsi nedeniyle merkezimizde takip edilen, VPA tedavisi alan, çalışma döneminde yaşları 3-18 (yıl) arasında olan 85 hastanın verileri analiz edildi. İstatistiksel analiz için araştırmaya dâhil edilen 85 hastaların ilk başvurusunda, tedavi başladıktan sonra 1. Yıl ve 2. Yıl bitimindeki veriler kullanıldı. Çalışma örnekleminin demografik ve klinik verileri Tablo 1'de sunulmuştur.

\section{Tablo 1. Valproik asit ile tedavi edilen hastaların} demografik özellikleri

\begin{tabular}{lc} 
& $\mathbf{N}(\%)$ \\
\hline Hasta Sayısı & 85 \\
Cinsiyet (Erkek/Kız) & $50 / 35(59 / 41)$ \\
Yaş (yıl) & $10.52 \pm 3.63$ \\
\hline
\end{tabular}

\section{Demografik, klinik ve temel laboratuvar verileri}

Çalışmamıza dâhil edilen VPA kullanan hastalardan 35'ini $(\% 41,1)$ erkekler, 50'sini ise kızlar oluşturmaktaydı. Yapılan çalışma sonuçlarına göre genel kanı cinsiyet ile prognoz arasında ilişki olmadığı yönündedir.

Çalışmamıza dâhil edilen hastalar 3-18 yaş arasında olup ortalama 10,52 \pm 3,63 yıl şeklindedir (Tablo 1). Bununla birlikte kızların yaş ortalaması 10,645 $\pm 3,798$, erkeklerin yaş ortalaması ise 11,153 $\pm 2,898$ yıl olarak tespit edildi.

Başlangıç, tedavinin 1. yıl ve 2. yılındaki laboratuvar değerleri Tablo 2 ve $\mathbf{3}$ 'te özetlenmiştir. 


\begin{tabular}{|c|c|c|c|c|c|c|c|c|}
\hline & & \multicolumn{2}{|c|}{ Tedavi Başlangıcı } & \multicolumn{2}{|c|}{ 1. YII } & \multicolumn{2}{|c|}{ 2.yıl } & \multirow[b]{2}{*}{$\mathbf{p}$} \\
\hline & & Ortalama & SS ( \pm ) & Ortalama & SS ( \pm ) & Ortalama & SS ( \pm ) & \\
\hline \multirow{3}{*}{ 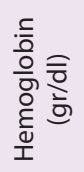 } & Total & 12,38 & 1,12 & 12,70 & 0,82 & 12,61 & 0,91 & 0,06 \\
\hline & $\mathrm{K} \mathbf{} \mathrm{z}$ & 12,19 & 1,06 & 12,45 & 0,96 & 12,37 & 1,11 & 0,06 \\
\hline & Erkek & 12,62 & 1,04 & 12,73 & 1,06 & 12,71 & 1,06 & 0,21 \\
\hline \multirow{3}{*}{ 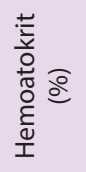 } & Total & 36,66 & 2,99 & 38,33 & 2,31 & 38,55 & 2,31 & 0,04 \\
\hline & $\mathrm{K} \mathrm{Iz}$ & 36,95 & 3,03 & 37,50 & 2,93 & 37,50 & 2,93 & 0,07 \\
\hline & Erkek & 38,32 & 3,07 & 38,71 & 3,12 & 38,98 & 2,90 & 0,86 \\
\hline \multirow{3}{*}{ 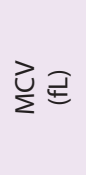 } & Total & 82,38 & 5,11 & 82,92 & 5,31 & 82,26 & 0,91 & 0,30 \\
\hline & $\mathrm{K} \mathrm{Iz}$ & 82,44 & 6,67 & 83,33 & 7,54 & 82,76 & 6,48 & 0,76 \\
\hline & Erkek & 82,98 & 5,31 & 82,98 & 4,79 & 82,90 & 5,16 & 0,71 \\
\hline \multirow{3}{*}{ 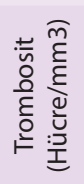 } & Total & 275,47 & 82,11 & 254,66 & 62,66 & 249,32 & 48,77 & 0,005 \\
\hline & $\mathrm{K} \mathrm{Iz}$ & 285,56 & 91,55 & 259,79 & 66,78 & 258,73 & 69,02 & 0,06 \\
\hline & Erkek & 268,19 & 67,90 & 261,31 & 72,90 & 249,47 & 65,15 & 0,16 \\
\hline \multirow{3}{*}{ 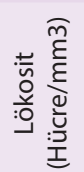 } & Total & 7,88 & 3,11 & 7,86 & 1,64 & 7,88 & 2,03 & 0,47 \\
\hline & $\mathrm{K} \mathrm{Iz}$ & 7,71 & 2,55 & 7,65 & 2,00 & 7,84 & 1,97 & 0,15 \\
\hline & Erkek & 7,49 & 2,10 & 7,66 & 2,01 & 7,60 & 2,11 & 0,17 \\
\hline
\end{tabular}

\begin{tabular}{|c|c|c|c|c|c|c|c|c|}
\hline & & \multicolumn{2}{|c|}{ Tedavi Başlangıcı } & \multicolumn{2}{|c|}{ 1. YII (U/L) } & \multicolumn{2}{|c|}{ 2.yıl (U/L) } & \multirow[b]{2}{*}{$\mathbf{p}$} \\
\hline & & Ortalama & SS ( $( \pm)$ & Ortalama & SS ( \pm ) & Ortalama & SS ( \pm ) & \\
\hline \multirow{3}{*}{ 号 } & Total & 12,38 & 1,12 & 12,70 & 0,82 & 12,61 & 0,91 & 0,06 \\
\hline & $\mathrm{KIz}$ & 242,42 & 52,83 & 244,83 & 56,89 & 248,11 & 49,89 & 0,14 \\
\hline & Erkek & 294,54 & 98,85 & 257,28 & 56,36 & 267,23 & 65,89 & 0,48 \\
\hline \multirow{3}{*}{ 足 } & Total & 220,80 & 79,75 & 205,88 & 55,79 & 195,44 & 41,13 & 0,17 \\
\hline & $\mathrm{KIz}$ & 241,13 & 195,36 & 221,0 & 73,15 & 212,97 & 59,41 & 0,31 \\
\hline & Erkek & 281,08 & 138,98 & 228,08 & 65,36 & 236,41 & 59,60 & 0,11 \\
\hline \multirow{3}{*}{ 导さ } & Total & 14,74 & 7,17 & 13,28 & 5,18 & 13,52 & 4,32 & 0,29 \\
\hline & $\mathrm{KIz}$ & 14,92 & 9,85 & 12,96 & 5,70 & 12,72 & 3,50 & 0,85 \\
\hline & Erkek & 15,28 & 5,58 & 14,44 & 5,06 & 14,80 & 6,59 & 0,77 \\
\hline \multirow{3}{*}{ 炎き } & Total & 27,15 & 8,87 & 24,64 & 3,91 & 25,87 & 5,61 & 0,02 \\
\hline & $\mathrm{KIz}$ & 26,84 & 11,02 & 23,62 & 5,90 & 24,98 & 6,17 & 0,01 \\
\hline & Erkek & 27,80 & 9,37 & 25,66 & 6,67 & 26,13 & 7,60 & 0,70 \\
\hline \multirow{3}{*}{ 䜣 } & Total & 18,22 & 17,78 & 18,96 & 11,22 & 20,40 & 11,21 & 0,02 \\
\hline & $\mathrm{KIz}$ & 20,89 & 23,42 & 22,27 & 26,58 & 21,30 & 24,74 & 0,11 \\
\hline & Erkek & 18,80 & 14,83 & 18,26 & 12,82 & 20,51 & 13,66 & 0,01 \\
\hline
\end{tabular}

\section{Tam Kan sayımı}

VPA kullanan hastaların tedaviye başlamadan önceki $\mathrm{Hb}$ değerleri ortalama 12,38 $\pm 1,12 \mathrm{gr} / \mathrm{dL}$, iken yıllar içinde artma eğilimi göstermekle birlikte bu farklılık istatistiksel olarak anlamlı bulunamamıştır $(p=0,06)$. Cinsiyete göre değerlendirildiğinde ise yıllar içerisindeki değişim cinsiyetler arasında farklılık göstermemektedir $(p=0,56)$. Hastaların tedaviye başlamadan önceki Htc değerleri ortalama $37,66 \pm 2,996 \%$, yıllar içinde artış eğilimi göstermiş bu farklılık istatistiksel olarak da anlamlı bulunmuştur $(F=3,350, p=0,04)$. Cinsiyetler arasında ise yıllara göre anlamlı bir farklılık yoktur $(p=0,67)$. Hastaların tedaviye başlamadan önceki MCV değerleri ortalama $82,38 \pm 5,110 \mathrm{fL}$ yıllar içindeki bu farklılık istatistiksel olarak anlamlı değildir $(p=0,30)$. Benzer şekilde cinsiyetler arasında ise yıllara göre anlamlı bir farklılık bulunamamıştır $(p=0,84)$. Hastaların tedaviye başlamadan önceki Plt değerleri yıllar içine azalma eğilimi göstermektedir ve bu farklılık istatistiksel olarak anlamlıdır $(F=6,453, p=0,005)$. Cinsiyetler arasında ise yıllara göre anlamlı bir farklılık bulunamamıştır $(p=0,56)$. 
Hastaların tedaviye başlamadan önceki WBC değerleri yıllar içinde ve cinsiyetlere göre farklılık göstermiş fakat bu farklılık istatistiksel olarak anlamlı değildir $(p=0,47)$. Valproik asit kullanan hastalar cinsiyetlerine göre gruplandırılıp tedavi yılları içindeki değişim değerlendirildiğinde kız ve erkek hastalarda $\mathrm{Hb}, \mathrm{Hct}$, MCV, WBC değerleri arasında yıllar içerisinde anlamlı bir farklılık saptanamamıştır ( $p>0,05)$.

\section{Karaciğer fonksiyon testleri ve amilaz seviyeleri}

Valproik asit kullanan hastalarda AST ve ALT değerleri normal değer aralığında olmakla beraber daha düşük $(p<0.05)$ olduğu tespit edilmiştir.

Valproik asit kullanan hastaların GGT değerleri yıllar içinde başlangıca göre artma göstermiş olup bu farklılık istatistiksel olarak anlamlıdır ( $F=4,359, p=0,02)$. Cinsiyete göre değerlendirildiğinde ise kızlar ve erkekler arasında anlamlı bir farklılık saptanmıştır $(p=0,03)$. GGT değeri erkek hastalarda başlangıç ölçümüne göre artış göstermiş ve farklılık istatistiksel olarak anlamlıdır $(p=0,01)$.

Cinsiyete göre VPA kullanan erkek ve kızlar karşılaştırıldığında tedavi öncesine göre tedavi sonrası artış istatistiksel olarak anlamlı bulunmuştur. $(p<0.05)$

Erkek çocuklarda tedavi öncesine göre tedavi sonrası GGT deki artış istatistiksel olarak anlamlı bulunmuştur. $(p<0.05)$

Hastaların tedaviye başlamadan önceki ALT, LDH ve ALP değerleri cinsiyete göre ve tedavi yıllarına göre anlamlı farklılık göstermemiştir. ( $p>0,05)$. Hastaların GGT değerleri yıllar içinde başlangıca göre artma göstermiş olup bu farklılık istatistiksel olarak anlamlıdır ( $F=4,359, p=0,02)$. Cinsiyete göre değerlendirildiğinde ise kızlar ve erkekler arasında anlamlı bir farklılık saptanmıştır $(p=0,03)$.

Ayrıca ALT, LDH ve ALP değerlerinde de yıllar içerisinde anlamlı bir farklılık yoktur. Ancak AST değeri kızlarda yıllar içerisinde başlangıca göre düşüş göstermiş ve bu farklılık istatistiksel olarak da anlamlı bulunmuştur $(p=0,01)$.

Her ne kadar laboratuvar değerlerinde istatistiksel olarak anlamlı değişimler olsa da değerler normal sınırlar içinde kaldığından tedavi değişikliğine gerek duyulmamıştır.

\section{TARTIŞMA}

Trombositopeni VPA'nın en sık görülen yan etkisidir, insidansı \%5-60 arasında değişmektedir $(26,27)$. Çocuklar daha çok etkilenir ve bu büyük olasılıkla VPA'nın çocukluk yaş grubunda daha sık kullanılmasına bağlıdır (28). Bizim çalışmamıza paralel olarak VPA'nın platelet düzeyini düşürdüğüne yönelik birçok çalışma, yüksek VPA serum düzeylerine bağlı olarak trombositopeninin geliştiğini göstermiştir (8,26-29). Bildirilmiş bir vaka dışında VPA eksikliğinin yol açtığı trombositopeniye bağlı ciddi kanama semptomları görülmemiştir $(28,30)$.
Trombositopeni yapan mekanizma tam olarak bilinmese de iki olasılık öne sürülmektedir; Bunlardan ilki VPA'nın direk kemik iliği üzerine toksik etkisi, diğeri ise trombositlere karşı otoantikor gelişimidir (8,2729,31).

Kishi ve arkadaşları toksik etkinin 120 mg/l kan konsantrasyonu üzerinde geliştiğini gözlemlemişlerdir (29). Sandler ve ark. VPA da bulunan dallı zincirli karboksilik asidin trombosit memranındaki yağ asidi kompenentiyle benzer olması sebebiyle otoantikorların (IgM) oluşumuna neden olabileceğini bildirmişlerdir (31).

Tetzlaff, trombosit sayısı normal olduğu halde operasyon sırasında ciddi kanaması olan bir vaka yayınlamıştır (32). Tek dozVPA kullanımının bile trombosit fonksiyonlarında bozulmaya neden olabileceği bildirilmiştir (33). Zeller ve arkadaşları flow-sitometrik yöntemle trombositlerdeki fonksiyon bozukluğunu göstermişlerdir (34). Kis ve arkadaşları yaptıkları çalışmada çok düşük düzeylerdeki VPA kan düzeylerinde bile trombositlerdeki araşidonik asit kaskadınının aktivitesinin dolayısıyla siklooksijenaz yolunun inhibisyonu ile güçlü bir trombosit agregatörü olan tromboksan A2 nin sentezinin bozulduğunu saptamışlar ve bunun trombosit fonksiyon bozukluğuna yol açarak kanama diatezlerin neden olduğu sonucuna varmışlardır (33). Klinik faydalarına rağmen, VPA ayrıca ilaca bağlı yan etkiler için bir örnek durumundadır. Özellikle, kronik olarak VPA alan hastalarda hemorajik pankreatit, kemik iliği baskılanması ve daha sık olarak hepatik hasar gelişebilir $(2,35)$. Bu nedenle, hastaların \% 44 kadarında, VPA, tedavinin ilk aylarında serum karaciğer enzimlerini ve lipid peroksidasyonunu yükseltir. Amitai ve ark. çalışma örnekleminde ortalama PLT sayısında bir azalma gözlemledi. Trombositopeni gelişme yüzde üç olarak bulundu. Literatürden farklı olarak PLT sayısı ile yaş veya VPA düzeyi arasında bir ilişki bulunmamıştır (37).

Bölükbaşı ve arkadaşlarının çalışmasında, sağlıklı ve epileptik kontrol gruplarında AST ve ALT değerleri normal değer aralığında yer almakla beraber epileptik kontrol grubunda AST değerlerinin daha düşük seviyelerde olduğu ve bu bulgunun klinik olarak anlamlı olduğu $(p<0.05)$ tespit edilmiştir (38). Bizim çalışmamızda Bölükbaşı ve arkadaşlarının çalışmasına paralel olacak şekilde başlangıç değerine göre tedavinin 1.ve 2 . yıl sonrası AST değerinde düşme tespit edilmiş ve bu istatistiksel olarak anlamlı çıkmıştır. $(\mathrm{p}<0.05)$.

Valproik asit kullanan hastalarda AST ve ALT değerleri normal değer aralığında olmakla beraber daha düşük $(p<0.05)$ olduğu, epilepsi kontrol grubu ile karşılaştırıldığında ise anlamlı fark olmadığı tespit edilmiştir. AST ve ALT değerlerinin düşük olması valproik asidin enzim inhibisyonu yapıcı etkisi ile ilişkili olabilir. Valproik asidin karaciğer aminotransferazlarında 
\%10-15 oranında geçici bir yükselmeye yol açtığı gösterilirken literatürde bu değişikliklerin valproik asitin en yaygın etkileri olduğu bildirilmektedir (32,33,3840). Antiepileptik ilaç tedavisinin karaciğer hasarına yol açabileceği eski ilaçlardan valproik asit ve yenilerden felbamatın fulminan karaciğer yetmezliği yapabileceği bildirilmiştir (40). Sönmez ve ark. (2006) ise valproik asit kullananlarda AST ve ALT düzeylerinde anlamlı değişiklik olmadığını belirtmişlerdir (41). Terapötik dozlarda VPA tedavisi gören epilepsili bir hasta kohortunda herhangi bir hepatotoksisite kanıtı gözlemlemeyen Haznedar ve meslektaşlarının araştırmalarıyla da tutarlıdır (24). Nijeryada yürütülen yakın tarihli araştırmada ise yine çocuklarda sodyum valproat monoterapisinin anlamlı hepatotoksisite ile ilişkili görünmediği bildirilmiştir (42). İsrailde psikiyatrik nedenlerle uzun dönem VPA tedavisi alan ergenler üzerinde yapılan araştırmada karaciğer enzimlerinde veya amilazda önemli bir değişiklik saptanmadığı ve hastaların hiçbirinde ciddi hepatotoksisite veya pankreatit gelişmediği bildirildi (37). Oysa bizim çalışmamızda VPA kullanımına bağlı olarak tedavi öncesi değere göre tedavi sonrası AST değerinde düşme olduğu tespit edilmiş ve bu istatistiksel olarak ta anlamlı bulunmuştur. $(p<0.05)$. Ayrıca VPA kullanan kız hasta grubu tedavi öncesi ve tedavi sonrası değerlendirildiğinde AST değerinde düşme tespit edilmiş ve bu istatistiksel olarak anlamlı bulunmuştur. $(p<0.05)$ GGT mikrozomal bir enzimdir ve ALP ile birlikte karaciğer atılım fonksiyonunda rol oynamaktadır. Valproik asitin mikrozomal enzim indüksiyonu yapmaması nedeniyle, VPA alan bir hastada karaciğer enzimleri yüksek olarak bulunduğunda hepatotoksisite akla gelebilmektedir. Ekskresyon enzimlerinin (GGT, ALP) mikrozomal enzim indüksiyonunu artırması sonucu biluribinlerin de atılımını arttırabileceği düşünülebilir (43). Oysa araştırmamızda VPA kullanan hastalarda GGT değerinde tedavi öncesine göre tedavi sonrası 1. ve 2. yıl sonrası artış olmuş bu değişim istatistiksel olarak ta anlamlı bulunmuştur.( $p<0.05$ )

Antiepileptik kullanımına bağlı artan osteoblastik aktiviteyi gösteren serum ALP yüksekliğini bildiren çok sayıda yayın vardır $(44,45)$. Voudris ve arkadaşlarının yaptığı çalışmada total ALP ve kemik, karaciğer, bağırsak ALP izoenzim düzeylerine bakılmış, karbamazepin ve fenobarbital alanlarda her ikisi de yüksek bulunmuş; valproik asit alanlarda kemik ALP izoenzimi yüksek bulunurken total ALP değerleri normal bulunmuştur 46. Bizim çalışmamızda ise VPA kullanımına bağlı tedavi öncesi değerlere göre her iki cinste de anlamlı bir değişim gözlenmemiştir. ( $p>0.05)$.

Kısıtlılık: Araştırma retrospektif olduğundan bazı verilere ulaşılamamıştır. Kan valproat düzeyi her hastada ölçülemediğinden ve veri yetersiz olduğundan kan ilaç düzeyi ve hematolojik ve biyokimysal parametreler üzerine etkisi incelenememiştir.

\section{SONUÇ}

Antiepileptik tedavinin başarılı bir şekilde yönetilmesinde, tedaviye ne zaman ve hangi ilaçla başlanacağı, hastanın hangi periyotlarda takip edileceği, tedaviyi sonlandırma zamanı, tedavinin başarısız olması halinde takip edilecek yol, ilave ilaç başlama veya ilaç değişiklikleri, tedavinin sonlandırılma zamanları ve ilaçların olası yan etkileri ile ilgili bilgilerin aile ile paylaşılması konusunda klinisyenin dikkatli olması gerekmektedir.

$\mathrm{Bu}$ çalışmada elde edilen VPA güvenlik profili, çoğu epileptik hastalarda gerçekleştirilen VPA tedavisi ile ilgili önceki çocuklar üzerinde yapılan çalışmalarda gözlemlenen sonuçlar ile benzerdir. Ayrıca, hematolojik ve karaciğer enzimleri gibi biyokimyasal parametrelerde izlenen değişimlere ek endokrinolojik değişiklikler gibi VPA ile ilişkili spesifik yan etkiler, özel dikkat gerektirir ve rutin tedavinin bir parçası olduğu bilinerek değerlendirilmelidir. Epileptik bozukluğu olan çocukların birden fazla ilaç kullanabileceği ve aynı zamanda metabolik ve endokrin olumsuzluklara daha yatkın olduğu göz önüne alındığında, VPA'nın hematolojik, biyokimyasal ve metabolik parametreler üzerindeki etkilerinin, diğer ilaçlarla da tedavi edilen hastalarda daha fazla incelenmesi önemlidir.

\section{ETIKK BEYANLAR}

Etik Kurul Onayı: Bu araştırmada 2020 öncesi veriler kullanılmış ve araştırma 2020 öncesinde sonuçlanmıştır. Yazarın 2014 yılında sunulan EPILEPTIK HASTALARDA VALPROIK ASIT VE KARBAMAZEPIN'IN HEMATOLOJIK VE BIYOKIMYASAL PARAMETRELERE ETKISI başlıklı tezinden üretilmiştir. 3 Kasım 2015 tarihli 28617 sayılı olarak resmi gazetede yayınlanan Klinik Araştırmalar Hakkında Yönetmelik'e göre "Retrospektif çalışmalar yönetmeliğin kapsamı dışındadır (madde 2-(2))"maddesi gereği etik kurul onayı alınmamıştır. Bu çalışma Kişisel Verilerin Korunması Kanununa uygun şekilde hasta verileri anonim hale getirtilerek ve İyi Kilinik Uygulamalar ve Helsinki Deklarasyonun 2013 Brezilya güncellemesine uygun olarak hazırlanmıştır.

Aydınlatılmış Onam: Çalışma retrospektif olarak dizayn edildiği için hastalardan aydınlatılmış onam alınmamıştır.

Hakem Değerlendirme Süreci: Harici çift kör hakem değerlendirmesi.

Çıkar Çatışması Durumu:Yazarlar bu çalışmada herhangi bir çıkara dayalı ilişki olmadığını beyan etmişılerdir.

Finansal Destek: Yazarlar bu çalışmada finansal destek almadıklarını beyan etmişlerdir.

Yazar Katkıları: Yazarların tümü; makalenin tasarımına, yürütülmesine, analizine katıldığını ve son sürümünü onayladıklarını beyan etmişlerdir. 


\section{KAYNAKÇA}

1. Soyuer F, Erdoğan F. Fiziksel aktivite ve Epilepsi. Sağlık Bilimler Dergisi (Journal of Health Sciences) 2011;20:77-81.

2. Kayış E, Yılmaz R, Karaaslan E. Childhood Epilepsy and Valproic Acid and Carbamazepine Treatment: Childhood Epilepsy. Chronicles of Precision Medical Researchers 2020;1:34-44.

3. Gültekin E, Turanlı G. Epilepsi. In: Yurdakök M, ed. Yurdakök Pediatri. Ankara: Güneş Tıp Kitapevleri; 2017:4385-8.

4. Görgülü Ü, Fesci H. Epilepsi ile yaşam: Epilepsinin psikososyal etkileri. Göztepe Tıp Dergisi 2011;26:27-32.

5. Toklu Z, Kutlu G, Demirbaş H, Koyuncu G, İnan LE. Ankara Eğitim ve Araştırma Hastanesi Epilepsi Polikliniğine başvuran epilepsi hastalarının demografik ve klinik bulguları. Epilepsi 2012;18:13-8.

6. Guerrini R. Epilepsy in children. The Lancet 2006;367:499-524.

7. Rosati A, De Masi S, Guerrini R. Antiepileptic Drug Treatment in Children with Epilepsy. CNS Drugs 2015;29:847-63.

8. Johannessen CU, Johannessen SI. Valproate: past, present, and future. CNS Drug Rev 2003;9:199-216.

9. Davis R, Peters DH, McTavish D. Valproic acid. A reappraisal of its pharmacological properties and clinical efficacy in epilepsy. Drugs 1994;47:332-72.

10. Tran AR, Zito JM, Safer DJ, Hundley SD. National trends in pediatric use of anticonvulsants. Psychiatr Serv 2012;63:1095-101.

11. Okay IT, Kısa C, Dilbaz N. Psikiyatrik bozukluklarda valproat kullanımı. Klinik Psikiyatri 2002;5:33-41.

12. Belcastro V, D'Egidio C, Striano P, Verrotti A. Metabolic and endocrine effects of valproic acid chronic treatment. Epilepsy Res 2013;107:1-8.

13. Abaci A, Saygi M, Yis U, Demir K, Dirik E, Bober E. Metabolic alterations during valproic acid treatment: a prospective study. Pediatr Neurol 2009;41:435-9.

14. Aggarwal A, Rastogi N, Mittal H, Chillar N, Patil R. Thyroid hormone levels in children receiving carbamazepine or valproate. Pediatr Neurol 2011;45:159-62

15. Aygün F, Ekici B, Aydinli N, Aydin BK, Baş F, Tatli B. Thyroid hormones in children on antiepileptic therapy. Int J Neurosci 2012;122:69-73.

16. Voudris K, Attilakos A, Katsarou E, et al. Serum total amylase, pancreatic amylase and lipase activities in epileptic children treated with sodium valproate monotherapy. Brain Dev 2006;28:572-5.

17. Gerstner T, Büsing $D$, Bell N, et al. Valproic acid-induced pancreatitis: 16 new cases and a review of the literature. Gastroenterol 2007;42:39-48.

18. Grauso-Eby NL, Goldfarb O, Feldman-Winter LB, McAbee GN Acute pancreatitis in children from Valproic acid: case series and review. Pediatr Neurol 2003;28:145-8.

19. Schmid MM, Freudenmann RW, Keller F, et al. Non-fatal and fata liver failure associated with valproic acid. Pharmacopsychiatry 2013;46:63-8.

20. Geller $B$, Luby JL, Joshi $P$, et al. A randomized controlled trial of risperidone, lithium, or divalproex sodium for initial treatment of bipolar I disorder, manic or mixed phase, in children and adolescents. Arch Gen Psychiatry 2012;69:515-28.

21. Pavuluri MN, Henry DB, Carbray JA, Sampson G, Naylor MW, Janicak PG. Open-label prospective trial of risperidone in combination with lithium or divalproex sodium in pediatric mania. J Affect Disord 2004;82 Suppl 1:S103-11.

22. Brigo F, Igwe SC, Lattanzi S. Ethosuximide, sodium valproate or lamotrigine for absence seizures in children and adolescents. Cochrane Database Syst Rev 2021;1:Cd003032.

23. Tolou-Ghamari Z, Zare M, Habibabadi JM, Najafi M-R. Antiepileptic drugs: a consideration of clinical and biochemical outcome in patients with epilepsy. international journal of preventive medicine 2013;4:330-7.

24. Haznedar P, Doğan Ö, Albayrak P, et al. Effects of levetiracetam and valproic acid treatment on liver function tests, plasma free carnitine and lipid peroxidation in childhood epilepsies. Epilepsy Res 2019;153:7-13.

25. Lo SF. Reference intervals for laboratory tests and procedures. Nelson textbook of pediatrics. 19 ed. Philadelphia: Elsevier; 2011.

26. Cannizzaro E, Albisetti M, Wohlrab G, Schmugge M. Severe bleeding complications during antiepileptic treatment with valproic acid in children. Neuropediatrics 2007;38:42-5.
27. May RB, Sunder TR. Hematologic manifestations of long-term valproate therapy. Epilepsia 1993;34:1098-101.

28. Cheng R. Thrombocytopenia associated with valproic acid that requires platelet transfusion. Ann Neurol 1989;26:457-8.

29. Kishi T, Fujita N, Kawaguchi H, Ishimae M, Watanabe K, Tanaka T. Bone marrow suppression induced by high dose valproic acid. Archives of disease in childhood 1994;71:153-5.

30. Acharya S, Bussel JB. Hematologic toxicity of sodium valproate. Journal of pediatric hematology/oncology 2000;22:62-5.

31. Sandler R, Emberson C, Roberts G, Voak D, Darnborough J, Heeley A. IgM platelet autoantibody due to sodium valproate. British medical journal 1978;2:1683.

32. Tetzlaff JE. Intraoperative defect in haemostasis in a child receiving valproic acid. Canadian journal of anaesthesia 1991;38:222.

33. Kis B, Szupera Z, Mezei Z, Gecse Á, Telegdy G, Vécsei L. Valproate treatment and platelet function: the role of arachidonate metabolites. Epilepsia 1999;40:307-10.

34. Zeller JA, Schlesinger S, Runge U, Kessler C. Influence of valproate monotherapy on platelet activation and hematologic values. Epilepsia 1999;40:186-9.

35. Bedry R, Parrot F. Severe valproate poisoning. Réanimation 2004;13:324-33.

36. Zimmerman HJ, Ishak KG. Valproate-induced hepatic injury: analyses of 23 fatal cases. Hepatology 1982;2:591S-7S.

37. Amitai M, Sachs E, Zivony A, et al. Effects of long-term valproic acid treatment on hematological and biochemical parameters in adolescent psychiatric inpatients: a retrospective naturalistic study. Int Clin Psychopharmacol 2015;30:241-8.

38. Bölükbaşi N, Akar F, Bır S. Antiepileptik İlaçların Lipit Profili ve Karaciğer Enzimleri Üzerine Etkisi. Archives of Neuropsychiatry/ Noropsikiatri Arsivi 2011;48.

39. Ahmed SN, Siddiqi ZA. Antiepileptic drugs and liver disease. Seizure 2006;15:156-64.

40. Voudris KA, Attilakos A, Katsarou E, et al. Early and persistent increase in serum lipoprotein (a) concentrations in epileptic children treated with carbamazepine and sodium valproate monotherapy. Epilepsy research 2006;70:211-7.

41. Mujgan Sonmez F, Demir E, Orem A, et al. Effect of antiepileptic drugs on plasma lipids, lipoprotein (a), and liver enzymes. Journal of child neurology 2006;21:70-4.

42. Adedapo ADA, Demaki WE, Lagunju I. Non-Dose-Dependent Changes in Liver Enzyme Levels of Children With Epilepsy on Treatment With Sodium Valproate. Dose Response 2020;18:1559325820918445.

43. Yamatogi Y. Principles of antiepileptic drug treatment of epilepsy. Psychiatry and clinical neurosciences 2004;58:S3-S6.

44. Bjøm K, Gjerstad L, Bentdal $\varnothing$, Osnes S, Schrumpf E. Topiramate and fulminant liver failure. The Lancet 1998;352:1119.

45. Feldkamp J, Becker A, Witte O, Scharff D, Scherbaum W. Longterm anticonvulsant therapy leads to low bone mineral densityevidence for direct drug effects of phenytoin and carbamazepine on human osteoblast-like cells. Experimental and clinical endocrinology \& diabetes 2000;108:37-43.

46. Voudris K, Moustaki M, Zeis PM, et al. Alkaline phosphatase and its isoenzyme activity for the evaluation of bone metabolism in children receiving anticonvulsant monotherapy. Seizure 2002;11:377-80. 